\title{
EFFECT OF DIFFERENT DRYING METHODS ON MINT LEAVES PHYSICAL AND QUALITY PROPERTIES
}

\author{
Taha, A. T.*; Keshek, M. H.*; Baggash, M.*
}

\section{ABSTRACT}

Three drying methods were used for drying mint leaves, oven drying (40, 50, 60 and $\left.70^{\circ} \mathrm{C}\right)$, microwave drying (180, 360, 540, 720 and $\left.900 \mathrm{Watt}\right)$ and direct solar drying with three levels of load $(0.5,1.25$ and $\left.5 \mathrm{~kg} / \mathrm{m}^{2}\right)$.The drying characteristics and the quality aspects of the dried mint leaves were studied. From initial moisture content (7.65 g.w/g.d.m.) to achieve the equilibrium moisture content the drying time was 5 minutes by microwave drier at use powers 900 and 720 Watt with loading level $0.5 \mathrm{~kg} / \mathrm{m}^{2}$, while the highest time took for drying mint was 20 hours to achieve equilibrium moisture content when use oven drier at $40{ }^{\circ} \mathrm{C}$. Meanwhile, the solar drier required $8 \mathrm{hr}$. to achieve the final moisture content of mint leaves $(0.11 \mathrm{~g} . w . / \mathrm{g} . \mathrm{d} . \mathrm{m})$ at both 1.25 and 0.5 $\mathrm{kg} / \mathrm{m}^{2}$ loading levels. The results showed that drying of the mint leaves at temperature $50{ }^{\circ} \mathrm{C}$ with loading rate $1.25 \mathrm{~kg} / \mathrm{m}^{2}$ was the best treatment from all treatments were studied in this work to getting the highest amount of essential oil. Midili - kucuk, model adequately described the oven and solar drying behaviors and logarithmic model adequately described the microwave drying behaviors.

Key wards: mint leaves, microwave, oven drying, solar drying,

\section{1-INTRODUCTION}

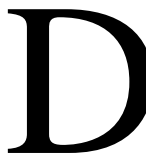

rying is one of the oldest methods of food preservation technique and it represents a very important aspect of food processing. The basic essence of drying is to reduce the moisture content of the product to a level that prevents deterioration within a certain period of time (Ekechukwu, 1999). Mint (Mentha piperita), is one of the most important and common flavor in the world coming after vanilla and citrus flavors. Fresh or dried leaves of mentha species are used as a condiment and also their essential oils are produced (Doymaz, 2006).

*Agricultural Engineering Department, Faculty of Agric., Minofiya University. 
Fresh herbs are most often sun dried and minced for flavoring several dishes. Sun drying permits one to produce a product with a rich color and a translucent appearance, but has many disadvantages such as slowness of the process, to exposure to environmental contamination, the dependency on weather and the hand labor requirement (Maskan, 2001).The drying method also had a significant effect on the proportion of the various components (Omidbaigi et al., 2004). Radünz (2004), after working with drying of mint common (Mentha villosaHuds), at temperatures between 50 and $70^{\circ} \mathrm{C}$, concluded that the air temperature of $50^{\circ} \mathrm{C}$ is recommended for drying mint-common in order to obtain the highest essential oil content and higher concentration of the main active constituents. Therdthai and Zhou (2009) determined the characteristics of microwave assisted vacuum drying of mint leaves in comparison with conventional hot air drying and their effects on the color and structure of the dried leaves required 13,12 and $10 \mathrm{~min}$, respectively for reducing the moisture content to less than $0.1 \mathrm{~kg}$ water $/ \mathrm{kg}$ dry sample.

The main objective of this experiment was to investigate the effect of different drying types (oven drying, solar drying and microwave drying) as well as different loading levels on drying characteristics and quality of mint leaves.

\section{2-MATERIALS AND METHODS}

\section{Plant material}

Fresh peppermint leaves (Mentha piperita.) was brought from locale market in El-Kom, Egypt.

\section{Microwave oven drier}

Microwave oven (KOR-9G2B) with maximum output of 900W and 2450 $\mathrm{MHz}$ was used for drying experiments. The Outside dimensions of the microwave were $465^{*} 280 * 282 \mathrm{~mm}$. cavity dimensions $(\mathrm{W} * \mathrm{H} * \mathrm{D})$ $314 * 235 * 346 \mathrm{~mm}$, and cavity volume $26 \mathrm{~L}$. glass plate with diameter 30 cm use to put the mint leaves on it.

\section{Oven drier:-}

Oven drier (Rumo-10878, Germany made) was used for drying experiments. The Outside dimensions of the oven drier $\left(\mathrm{W}^{*} \mathrm{H}^{*} \mathrm{D}\right)$ were $80 * 70 * 60 \mathrm{~cm}$. and cavity dimensions $(\mathrm{W} * \mathrm{H} * \mathrm{D}) 50 * 60 * 50 \mathrm{~cm}$. 
Solar drying system

The solar drier used in this study was designed and manufactured in the College of Agricultural Minofiya University Shibin El-kom and installed on the roof of Agricultural Engineering Department at (latitude $30.5^{\circ} \mathrm{N}$, longitude $31.3^{\circ} \mathrm{E}$, and altitude 16.2 meters from mean sea level) as shown in Fig (1). The solar drier consists of the following parts:-

\section{Solar collector (air heater)}

The solar collector was made of wooden box having gross dimensions of $1.0 \mathrm{~m}$ long, $0.75 \mathrm{~m}$ wide and $0.20 \mathrm{~m}$ deep. The walls and bottom was constructed of two layer of plywood ( $0.003 \mathrm{~m}$ thick) and the space between the two layer are insulated by foam layer ( $0.03 \mathrm{~m}$ thick), this box painted from inside and outside by a blackboard paint mixed with 50 $\%$ by weight of a talc powder . A corrugated absorber plate of surface area was $\left(0.62 \mathrm{~m}^{2}\right)$ made of galvanized iron sheet $0.5 \mathrm{~mm}$ thick. The solar collector was covered with one layer of an ordinary glass, $0.003 \mathrm{~m}$ thick. The solar collector was attached with the drying chamber by an air duct. The solar collector was oriented to face the south direction and tilted with an optimum tilt angle at noon.

\section{Drying chamber}

The side walls and bottom of drying chamber were constructed of two layer of plywood ( $0.003 \mathrm{~m}$ thick) and the space between the two layer are insulated by foam layer $(0.03 \mathrm{~m}$ thick $)$. The drying chamber was equipped by two drying trays which were made of wooden frame $(0.35 \mathrm{~m} \times 0.65$ m) and stainless steel screen mesh in the bottom, Fig. (1).

\section{Methods:}

Experimental procedure

The fresh mint leaves were washed with water and then excess water on the surface of leaves was drained. The moisture content of the fresh mint leaves was measured at $70{ }^{\circ} \mathrm{C}$ in an oven drier for 24 hours. Then the sample was divided into 3 parts each of them dried using different method as follow:

\section{Solar drying}

Peppermint leaves were distributed on three steel trays of size $0.1 * 0.1$, $0.2 * 0.2$ and $0.3 * 0.3 \mathrm{~m}$, as samples to be weighted with three levels of loading, $5,1.25$ and $0.5 \mathrm{~kg} / \mathrm{m}^{2}$, and put it on the trays of solar drier. 


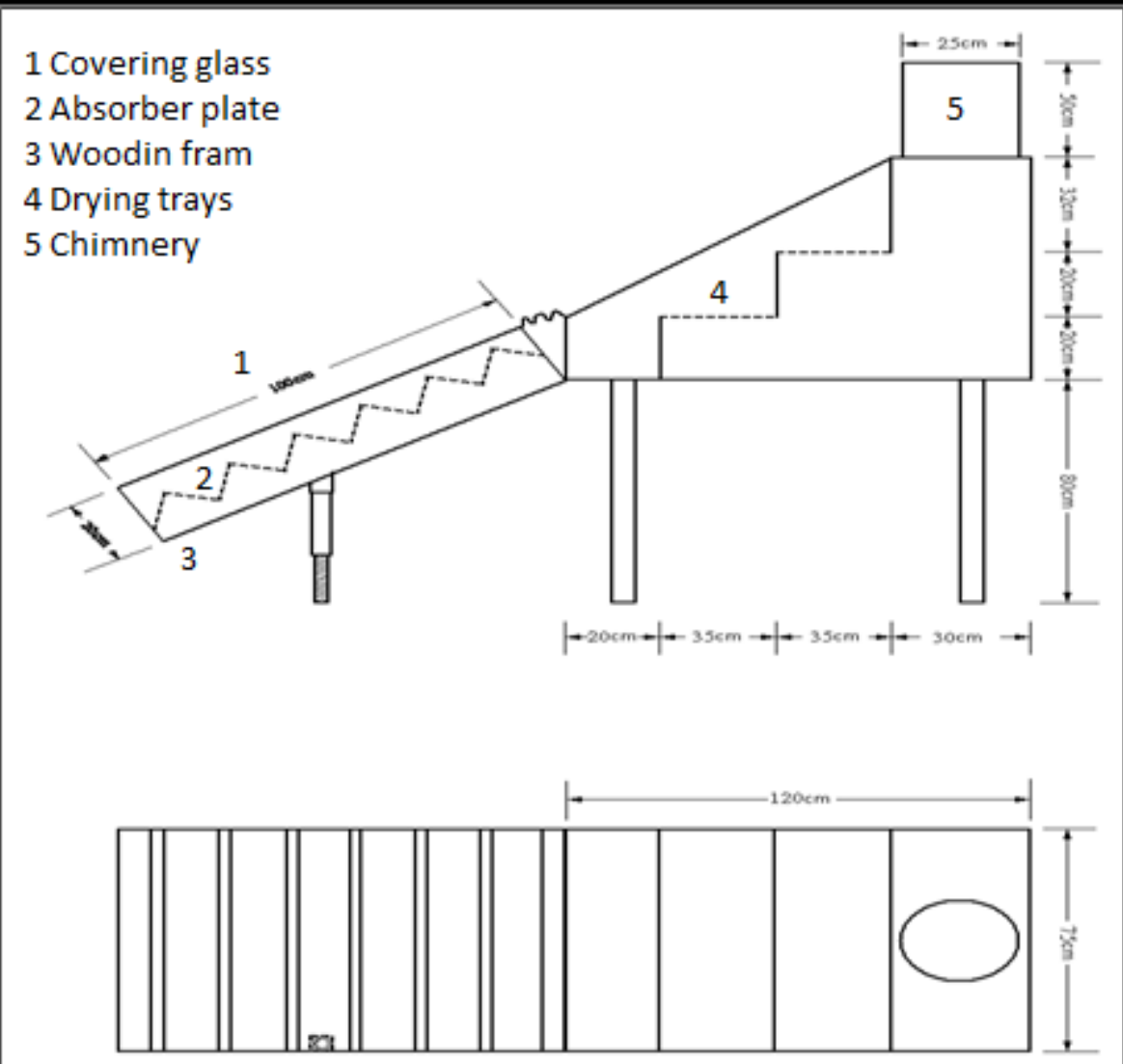

Fig. (1): Schematic diagram of solar drier.

The remaining free space of solar drier trays were used to put on it amount of mint with the same loading rates.

Microwave drying

Peppermint leaves were distributed uniformly in three levels of loading $0.5,1.25$ and $5 \mathrm{~kg} / \mathrm{m}^{2}$ on to the glass Microwave oven plate (dish) diameter $30 \mathrm{~cm}$, and the Microwave operated by different powers (180, 360, 540, 720 and 900 Watt).

\section{Oven drying}

Peppermint leaves were distributed on three steel trays of size $0.1 * 0.1$, 
$0.2 * 0.2$ and $0.3 * 0.3 \mathrm{~m}$, as samples to be weighted with three levels of loading, $5,1.25$ and $0.5 \mathrm{~kg} / \mathrm{m}^{2}$, and put it on the trays of oven drier. The remaining free space of oven drier trays were used to put on it amount of mint with the same loading rates.

\section{Taking data}

Drying data were obtained using three samples for peppermint which were weighted and positioned at the center and the two ends of each tray. The mass of the sample was measured every 1 hour during oven and solar drying and every 1 minute during microwave oven drying for mint leaves.

\section{Measurements:}

\section{Moisture content.}

The moisture content of fresh mint was determined according to El-Awady et al. (1993).

The moisture content of a material expressed on the dry basis $\left(\mathrm{M}_{\mathrm{db}}\right)$ by using the following equation:

$$
M_{d b}=\frac{w_{o}-w_{d}}{w_{d}} \times 100 \quad \%
$$

Where:

$$
\begin{aligned}
& \mathrm{W}_{\mathrm{o}}=\text { initial weight of fresh product } \\
& \mathrm{W}_{\mathrm{d}}=\text { weight of dry product }
\end{aligned}
$$

\section{The Drying Efficiency}

The drying efficiency $\eta_{D}$ is the ratio of the energy required to evaporate the moisture from the crop to available energy.

\section{solar Drier efficiency:}

Available energy was solar radiation falling on the area of the drying chamber only.

$$
\eta_{D s}=\frac{\mathrm{Wr} * \mathrm{Lv}}{\mathrm{I} * \mathrm{~A}} * 100
$$

Where :- 
$\mathrm{W}_{\mathrm{r}}=$ water removal, $(\mathrm{kg} / \mathrm{s})$

$\mathrm{L}=$ latent heat of vaporization, $2256.7 * 10^{3}$

$(\mathrm{J} / \mathrm{kg})$.

$\mathrm{I}=$ solar intensity on horizontal surface

$\left(\mathrm{W} / \mathrm{m}^{2}\right)$

$\mathrm{A}=$ surface area of dying chamber

$\mathrm{t}=$ desired time period

\section{Oven drier efficiency:}

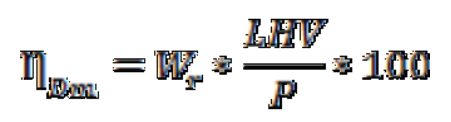

Where :

$\mathrm{W}_{\mathrm{r}} \quad$ = water removal $(\mathrm{kg} / \mathrm{s})$

LHV = Latent heat of vaporization $2256.7 * 10^{3}(\mathrm{~J} / \mathrm{Kg})$

$\mathrm{P} \quad=$ Power consumed $(\mathrm{W})$

$\mathrm{P}=\mathrm{V}^{*} \mathrm{I}^{*} \operatorname{COS} \varphi=1.159 \mathrm{KW}$.

Where :-

$\mathrm{V}=$ Voltage electrical, $230 \mathrm{~V}$

I = The intensity of electric current, 6.3 by clamp meter

$\operatorname{COS} \varphi=0.8$

Microwave drier efficiency:

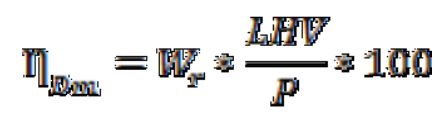

Where :

$$
\begin{aligned}
& \mathrm{W}_{\mathrm{r}}=\text { water removal } \\
& \mathrm{LHV}=\text { Latent heat of vaporization } 2256.7^{*} 10^{3} \\
& \mathrm{P} \quad=\text { Power consumed, } 1350
\end{aligned}
$$

Temperature: temperatures $\left({ }^{\circ} \mathrm{C}\right)$ were measured using a Rotronic Instruments UK ltd.

Essential oil determination: Fifty gram of the fresh and dried mint were placed in the distillation apparatus then let boil for 3 hours (Board ,2003) 
and the yielded oil was collected as the amount of oil per $100 \mathrm{~g}$ dry weight.

Chlorophylls measurement: The contents of total chlorophylls were calculated using the following equations according to El-Yateem (1995),

Chlorophyll A $=(9.78 \times \mathrm{E} 644)-(0.99 \times \mathrm{E} 644) \quad, \mathrm{mg} / \mathrm{liter}$

Chlorophyll B = (21.426×E 644) $-(4.65 \times \mathrm{E} 662) \quad, \mathrm{mg} / \mathrm{liter}$

where : $\quad E=$ sample optical density at the indicated wave length.

\section{Modeling the drying characteristics}

\section{Mathematical models of drying curves}

The methods drying curves were fitted with eleven different moisture ratio equations given by several researchers and cited by Idlimam et al., 2007, as listed in table 2.1.

\section{Fitting the mathematical models:}

The regression analysis was performed using the statistical computer program, (Data fit 9.0). The goodness fit between the predicted and experimental values of the tested mathematical models was evaluated from the coefficient of determination $\mathrm{R}^{2}$ and the reduced chi-square $\chi^{2}$. The higher of $\mathrm{R}^{2}$ values and the lower of $\chi^{2}$ values, the better is the goodness of fit Ertekin and Yaldiz, (2004). The reduced chi-square can be calculated as follow:-

$$
\begin{gathered}
M B E=\frac{1}{N} \sum_{i=1}^{N}\left(M R_{p r e, i}-M R_{\mathrm{exp}, i}\right) \\
\chi^{2}=\frac{\sum_{i=1}^{N}\left(M R_{\mathrm{exp}, i}-M R_{p r e, i}\right)^{2}}{N-n}
\end{gathered}
$$

Where:-

$\mathrm{MR}_{\text {exp,i }}$ : the experimental moisture ratio.

$\mathrm{MR}_{\text {pre, }}:$ the predicted moisture ratio.

$\mathrm{N}$ : number of observations

$\mathrm{n}$ : number of constants.

MBE: mean bias error was used to determine the quality of the fit. 
Table (1) Mathematical models applied to the drying curves Idlimam et al. (2007).

\begin{tabular}{|c|c|c|}
\hline $\begin{array}{l}\text { Model } \\
\text { number }\end{array}$ & Model name & Model expression \\
\hline 1 & Newton & $M R=\exp (-k \cdot t)=e^{-k \cdot t}$ \\
\hline 2 & Page & $\mathrm{MR}=\exp \left(-\mathrm{k} \cdot \mathrm{t}^{\mathrm{n}}\right)=\mathrm{e}^{-\mathrm{k} \cdot \mathrm{tn}}$ \\
\hline 3 & Henderson and Pabis & $\mathrm{MR}=\mathrm{a} \cdot \exp (-\mathrm{k} \cdot \mathrm{t})=\mathrm{a} \cdot \mathrm{e}^{-\mathrm{k} . \mathrm{t}}$ \\
\hline 4 & Logarithmic & $\mathrm{MR}=\mathrm{a} \cdot \exp (-\mathrm{k} \cdot \mathrm{t})+\mathrm{c}=\mathrm{a} \cdot \mathrm{e}^{-\mathrm{k} \cdot \mathrm{t}+\mathrm{c}}$ \\
\hline 5 & Two term & $\begin{array}{l}M R=a \cdot \exp \left(-k_{0} \cdot t\right)+b \exp \left(-k_{1} t\right) \\
=a \cdot e^{-k 0 . t}+b e^{-k 1 t}\end{array}$ \\
\hline 6 & Two term exponential & $\begin{array}{l}M R=a \cdot \exp (-k \cdot t)+(1-a) \exp (-k \cdot a \cdot t) \\
=a \cdot e^{-k \cdot t}+(1-a) e^{-k \cdot a \cdot t}\end{array}$ \\
\hline 7 & Wang and Singh & $\mathrm{MR}=1+\mathrm{a} \cdot \mathrm{t}+\mathrm{bt}^{2}=1+\mathrm{a} \cdot \mathrm{t}+\mathrm{bt}^{2}$ \\
\hline 8 & Approximation of diffusion & $\begin{array}{l}M R=a \exp (-k \cdot t)+(1-a) \exp (-k \cdot b \cdot t) \\
=a \mathrm{e}^{-k . t}+(1-a) \mathrm{e}^{-k . b . t}\end{array}$ \\
\hline 9 & Modified Henderson and Pabis & $\begin{array}{l}M R=a \exp (-k \cdot t)+b \cdot \exp (-g . t)+c \cdot \exp (-h \cdot t) \\
=a e^{-k . t}+b \cdot e^{-g . t}+c \cdot e^{- \text {-h.t }}\end{array}$ \\
\hline 10 & Verma & $\begin{array}{l}M R=a \exp (-k . t)+(1-a) \exp (-g . t) \\
=a e^{-k . t}+(1-a) e^{-g . t}\end{array}$ \\
\hline 11 & Midilli-Kucuk & $\begin{array}{l}M R=a \exp \left(-k \cdot t^{n}\right)+b \cdot t \\
=a e^{-k \cdot t n}+b \cdot t\end{array}$ \\
\hline
\end{tabular}

\section{Where}

MR : moisture ratio, $\mathrm{T}:$ time, $\mathrm{h}$ and $\mathrm{A}, \mathrm{b}, \mathrm{c}, \mathrm{g}, \mathrm{h}, \mathrm{k}, \mathrm{n}:$ constant

\section{RESULTS AND DISCUSSION}

Effect of Drying Methods on drying Characteristics of Peppermint leaves Mint leaves with initial moisture content (7.65 ) g.w./g.d.m. was dried by different drying methods (oven drying, solar drying and microwave drying) at different loading levels $\left(5,1.25\right.$ and $\left.0.5 \mathrm{~kg} / \mathrm{m}^{2}\right)$. The drying characteristics (moisture content, drying time, drying efficiency and energy consumption) were determined as the quality aspects of the dried mint leaves were evaluated.

\section{Effect of different drying methods on moisture content:-}

\section{Microwave drying:}

Fig. 2 ( $a, b$ and $c$ ) describe the microwave drying curves of moisture content versus drying time the microwave powers and the three loading levels. These figures show the equilibrium moisture content $(0.08) \mathrm{g}$. w./g. d. m. for mint leaves using microwave drying required a range between 205 and $5 \mathrm{~min}$ at five radiation powers $(180,360,540,720$ and $900 \mathrm{~W})$ with three loading levels $(5,1.25$ and $0.5 \mathrm{~kg} / \mathrm{m} 2)$. ). Where it 
required 205, 71, 48, 45 and $40 \mathrm{~min}$, respectively at loading leave 5 $\mathrm{kg} / \mathrm{m}^{2} ; 64,23,16,12$ and $12 \mathrm{~min}$, respectively at $1.25 \mathrm{~kg} / \mathrm{m}^{2}$ and $16,9,6$, 5 and 5 min respectively at $0.5 \mathrm{~kg} / \mathrm{m}^{2}$ of loading leave.

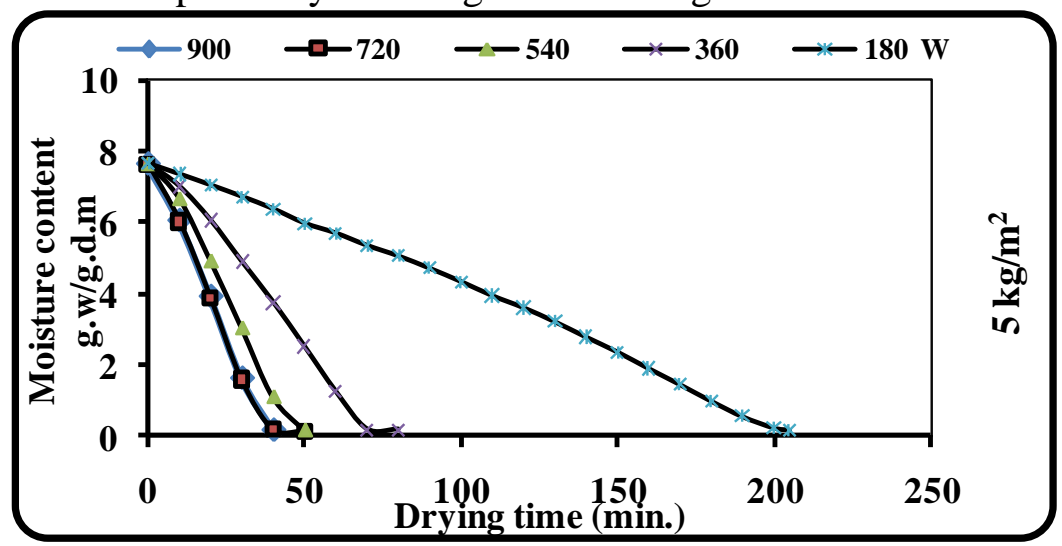

(a)

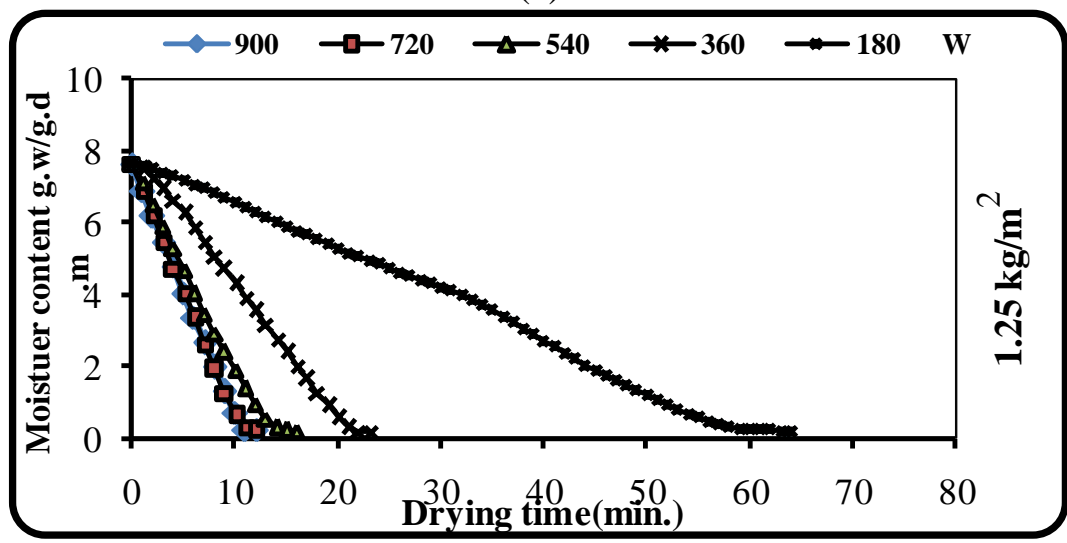

(b)

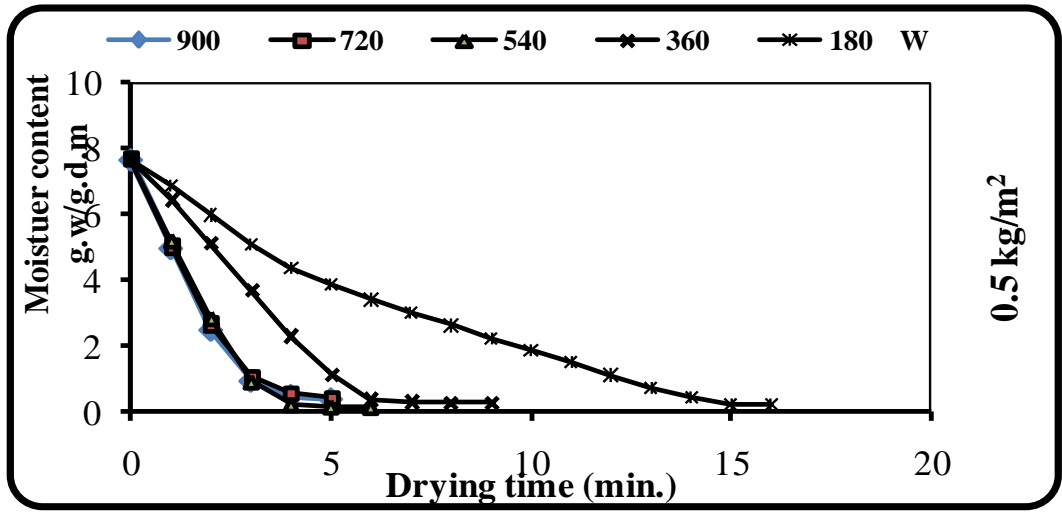

(c)

Fig. (3) Moisture degradation during microwave drying. 


\section{Oven drying:}

The effect of oven drying condition (temperature and loading) on moisture content of mint leaves are illustrated in Fig. 4 (a, b and c).

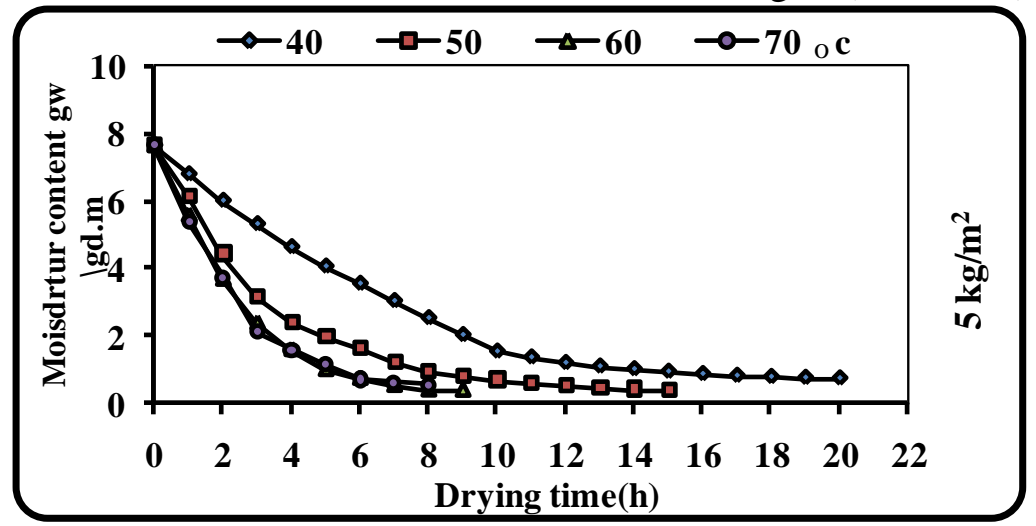

(a)

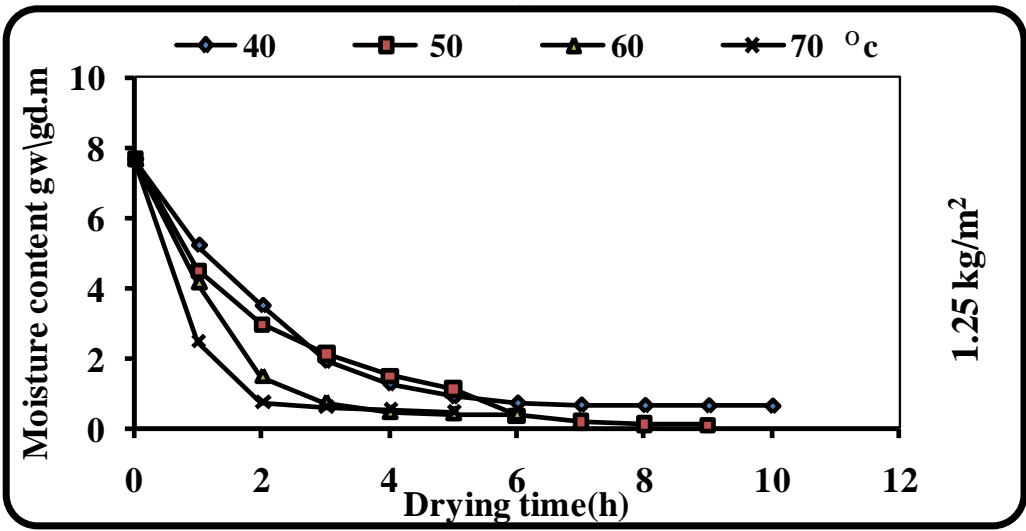

(b)

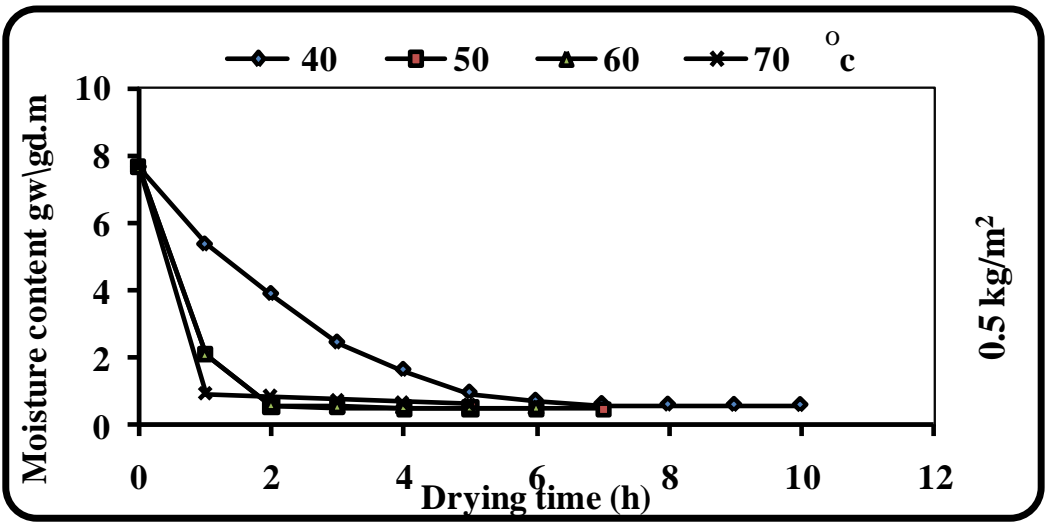

(c)

Fig. (4) Moisture degradation during oven drying. 
The moisture content of mint leaves was decreased with increasing drying time under the various drying conditions. achieving the equilibrium moisture content for mint leaves using different oven temperature $\left(40,50,60\right.$ and $70{ }^{\circ} \mathrm{C}$ ) with loading level $5 \mathrm{~kg} / \mathrm{m}^{2}$. While it required $10,9,6,5$, and $10,7,6$, 5hours at loading levels 1.25 and 0.5 $\mathrm{kg} / \mathrm{m}^{2}$, respectively. Remarkable difference in drying time was observed between drying at $40{ }^{\circ} \mathrm{C}$ and both 60 and $70{ }^{\circ} \mathrm{C}$. The drying time at $70{ }^{\circ} \mathrm{C}$ was about 60,50 and $50 \%$ shorter as compared with the drying time at $40^{\circ} \mathrm{C}$ with the levels $5,1.25$ and $0.5 \mathrm{~kg} / \mathrm{m}^{2}$, respectively. Meanwhile no remarkable difference in drying time among 50, 60 and $70{ }^{\circ} \mathrm{C}$ with loading levels $0.5,1.25 \mathrm{~kg} / \mathrm{m}^{2}$.

\section{Solar drying:}

Fig (5) describe the solar drying curves of moisture content versus drying time at three levels of loading. To achieve the save storage moisture content for mint leaves using solar drying it required 14,8 and 8 hours, at three loading $5,1.25$ and $0.5 \mathrm{~kg} / \mathrm{m}^{2}$,respectively. The result clearly maintained that no difference in drying time between loading levels 0.5 , $1.25 \mathrm{~kg} / \mathrm{m}^{2}$ which represent a drying time $43 \%$ shorter than the drying time at $5 \mathrm{~kg} / \mathrm{m}^{2}$ and it means that the loading $1.25 \mathrm{~kg} / \mathrm{m}^{2}$ was the better.

Drying time of mint leaves could be shortened by 42.8 and $35.7 \%$ by using oven driers at $70{ }^{\circ} \mathrm{C}$ and $60{ }^{\circ} \mathrm{C}$, respectively compared to solar drying (at $5 \mathrm{~kg} / \mathrm{m}^{2}$ loading). While Microwave drying shortened the drying time over than 95 and (83-98.5\%) when compared to the solar and oven drying methods.

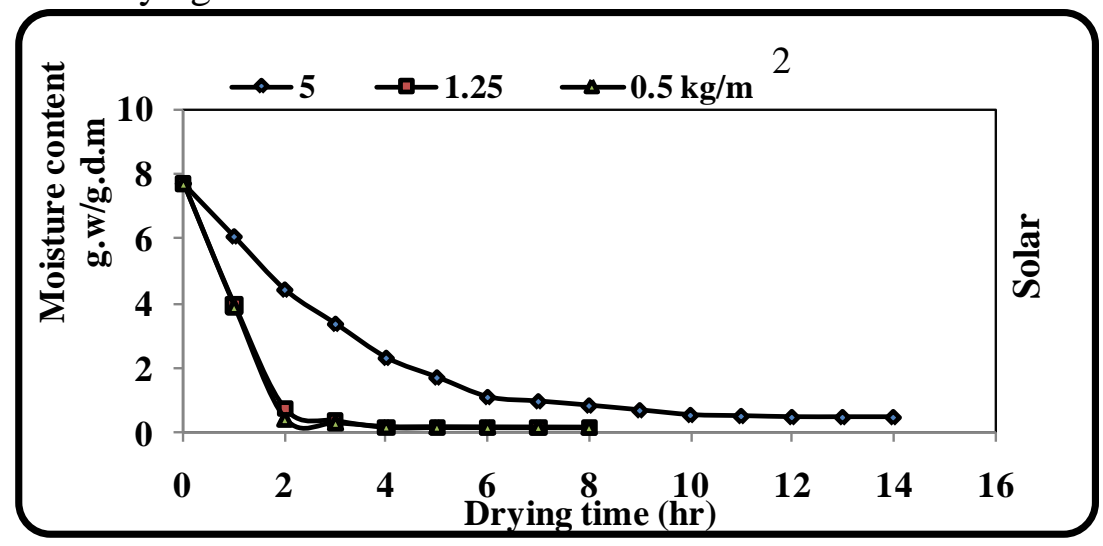

Fig. (5) Moisture degradation during solar drying. 
Effect of drying methods on drying efficiency:-

\section{Oven drying:}

Fig. $6(\mathrm{a}, \mathrm{b}$, and $\mathrm{c})$ describe the relation between the drying efficiency and oven drying time with three levels of loading $5,1.25$, and $0.5 \mathrm{~kg} / \mathrm{m}^{2}$ and different temperature $\left(40,50,60\right.$ and $\left.70{ }^{\circ} \mathrm{C}\right)$.

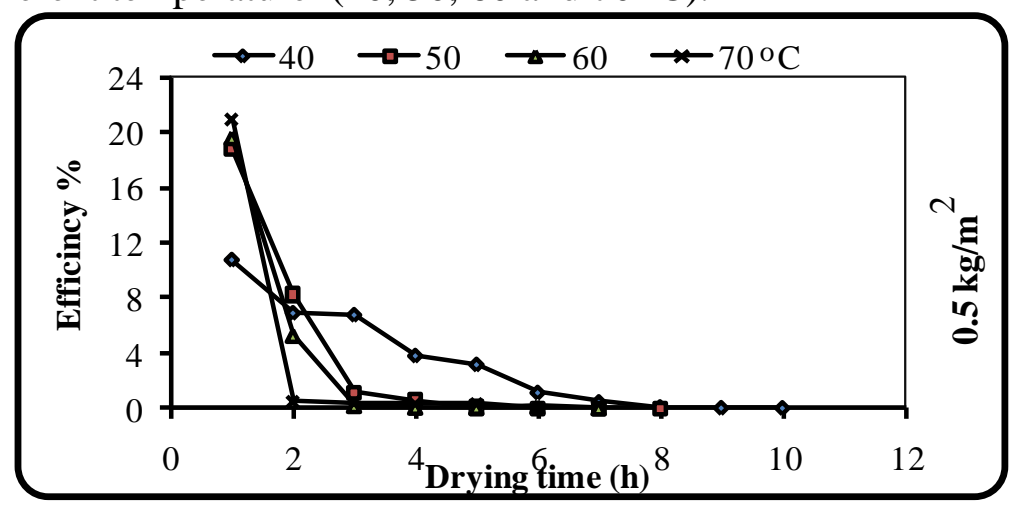

(a)

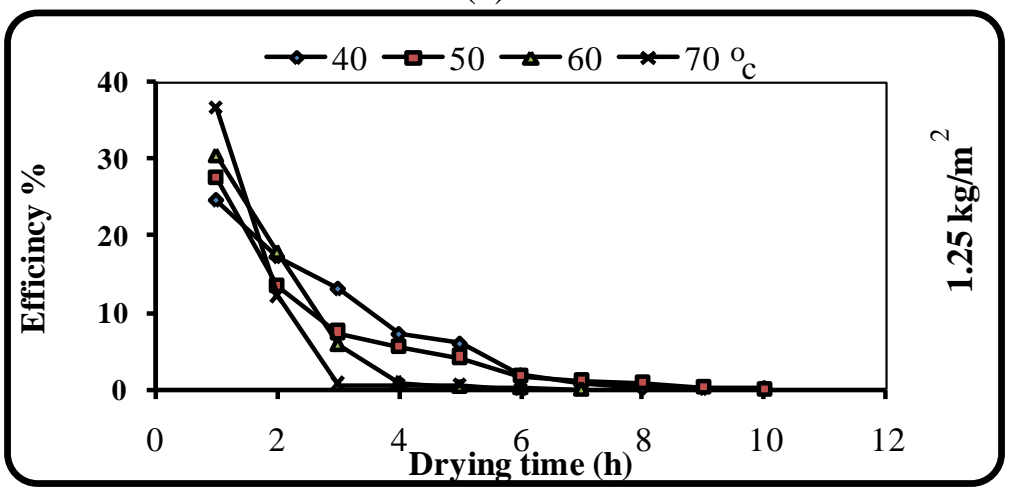

(b)

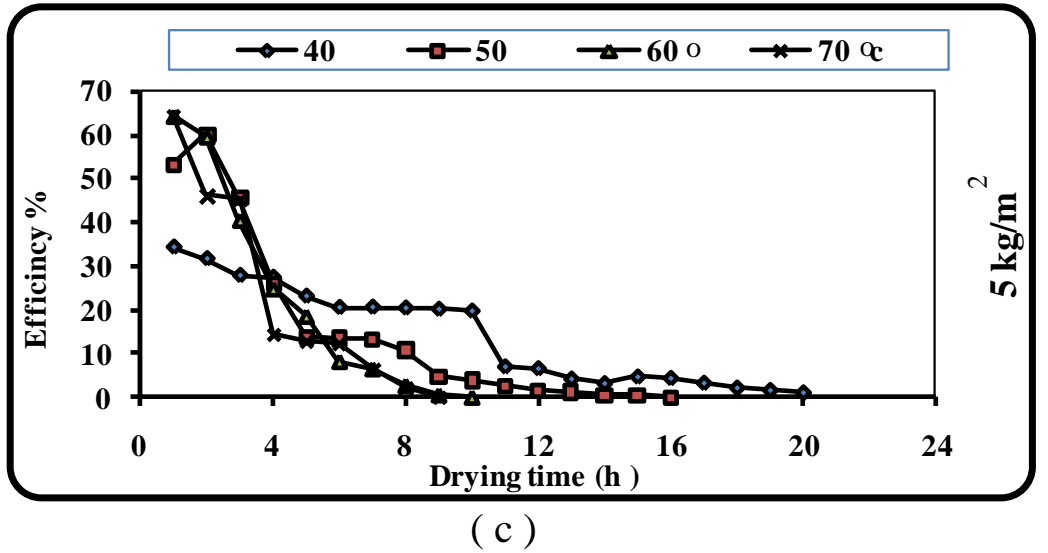

Fig. (6) relation shape between the drying efficiency and oven drying time 
The drying efficiency was always relative high at the beginning of the drying due to increase in drying rate. And wherever it could be noticed that the efficiency increased with increasing loading rate, where the highest efficiency was $64 \%$ at loading $5 \mathrm{~kg} / \mathrm{m}^{2}$ and $70{ }^{\circ} \mathrm{C}$. The lowest was $10 \%$ at $0.5 \mathrm{~kg} / \mathrm{m}^{2}$ and $40{ }^{\circ} \mathrm{C}$. On the other side, increasing loading rate to $5 \mathrm{~kg} / \mathrm{m}^{2}$ takes the longest period time this means more energy consumption.

\section{Solar drying:}

Fig. (7) describe the relation between the drying efficiency and solar drying time, the highest efficiency was $50 \%$ at levels $5,1.25$, and $0.5 \mathrm{~kg}$ $/ \mathrm{m}^{2}$ of loading. Meanwhile the lowest was $25 \%$ which recorded at 0.5 $\mathrm{kg} / \mathrm{m}^{2}$. The drying efficiency was always relative high at the beginning of the drying due to increase in drying rate.

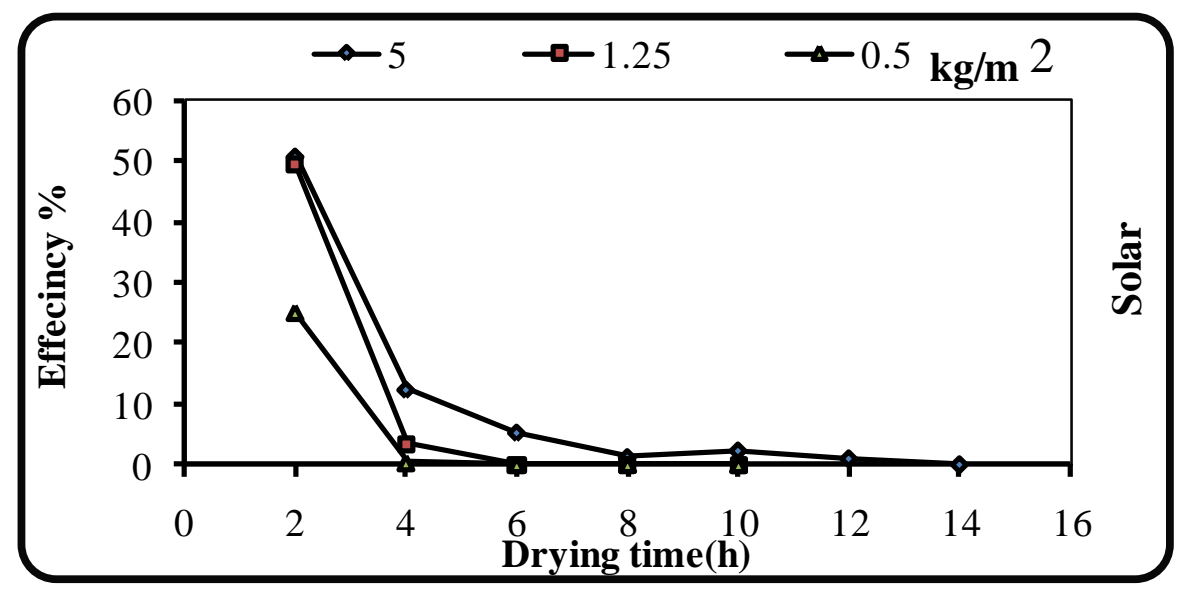

Fig. (7) relation shape between the drying efficiency and solar drying time

\section{Microwave drying:}

Fig. 8 ( $a, b$ and $c$ ) describes the relation between the drying efficiency and drying time with varies microwave power 180, 360, 540, 720 and $900 \mathrm{~W}$, at three levels of loading $0.5,1.25$ and $5 \mathrm{~kg} / \mathrm{m}^{2}$. The drying efficiency was always relative high at the beginning of the drying time due to increase in drying rate. The Figures show that the efficiency decreased with increasing loading rate, and it decreased with decreasing of microwave power. However the highest efficiency was $31 \%$ at loading level $0.5 \mathrm{~kg} / \mathrm{m}^{2}$ with $900 \mathrm{~W}$, and the lowest was $5 \%$ at loading 
level $5 \mathrm{~kg} / \mathrm{m}^{2}$ with $180 \mathrm{~W}$. Furthermore increasing of loading rate $\left(5 \mathrm{~kg} / \mathrm{m}^{2}\right)$ takes the longest period time, this means more energy consumption.

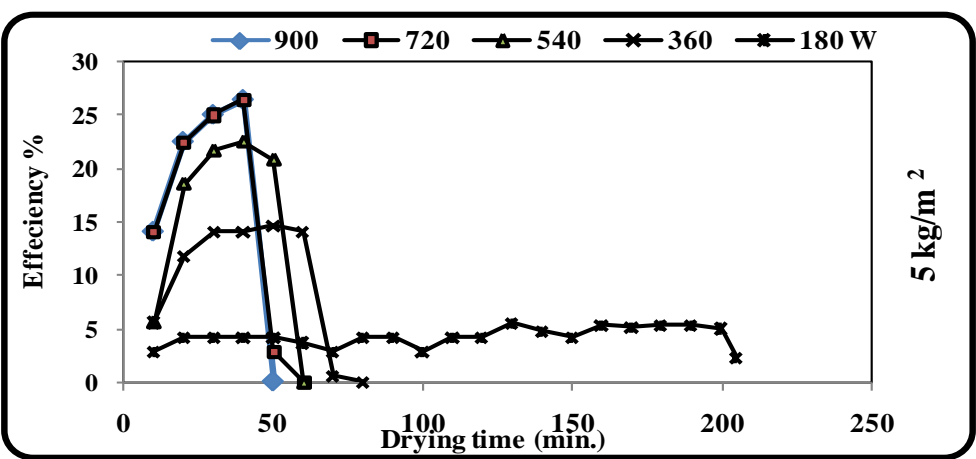

(a)

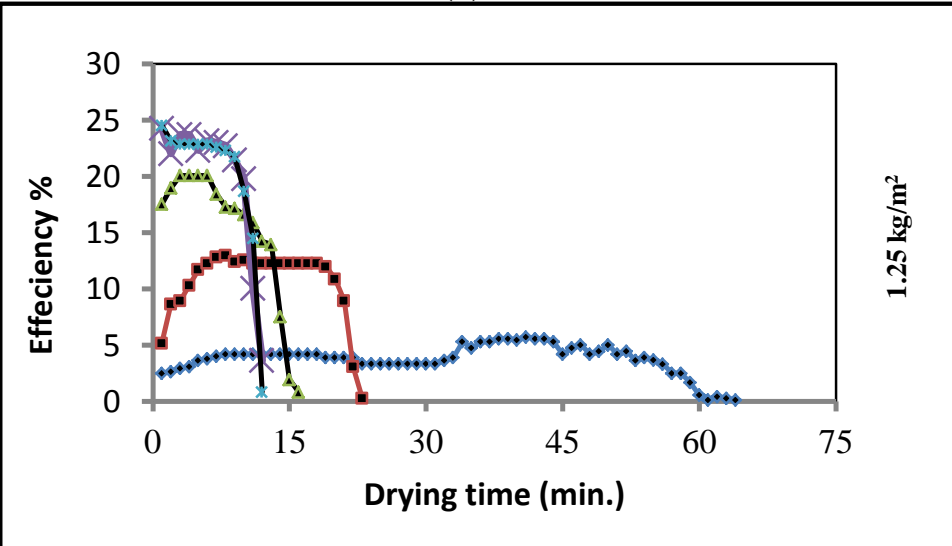

(b)

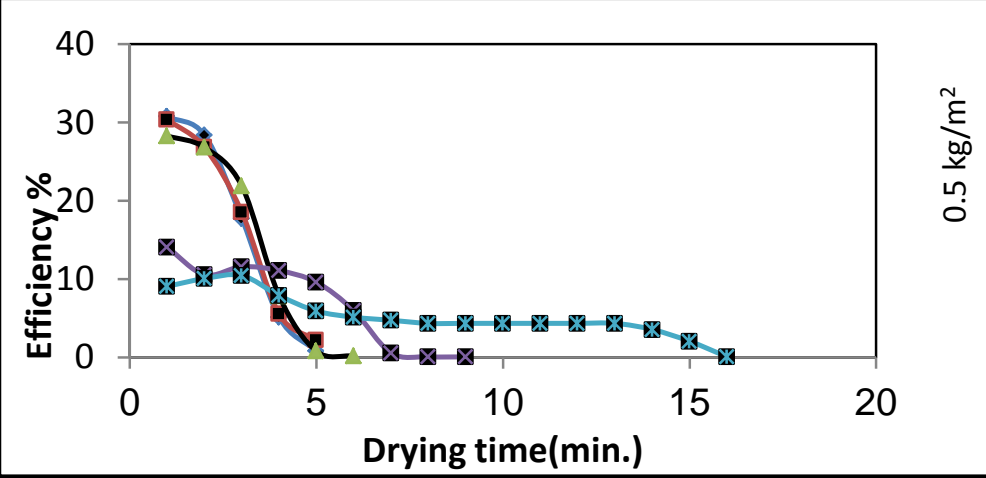

(c)

Fig. (8) relation shape between the drying efficiency ( \%) and microwave drying time(min) 


\section{Effect of drying methods on energy consumption:}

Table (1) shows consumed energy by different drying methods (oven drying, microwave drying and solar drying) during peppermint drying process. The highest value of energy consumption was $48.7 \mathrm{MJ}$ when used $40{ }^{\circ} \mathrm{C}$ with $5 \mathrm{~kg} / \mathrm{m}^{2}$ loading rate in oven drying, while the lowest value was $0.405 \mathrm{MJ}$ when used the microwave power 900 and $720 \mathrm{~W}$ at $0.5 \mathrm{~kg} / \mathrm{m}^{2}$ loading rate.

\section{Table (1) Total energy consumption during drying peppermint by different Drying methods (MJ)}

\begin{tabular}{|c|c|c|c|c|c|c|c|c|c|c|}
\hline \multirow{3}{*}{ 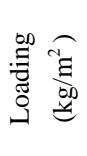 } & \multicolumn{10}{|c|}{ Drying methods } \\
\hline & \multicolumn{4}{|c|}{ Oven temperature $\left({ }^{\circ} \mathrm{C}\right)$} & \multirow{2}{*}{$\begin{array}{l}\text { Solar } \\
\text { drying }\end{array}$} & \multicolumn{5}{|c|}{ Microwave power (W) } \\
\hline & 40 & 50 & 60 & 70 & & 180 & 360 & 540 & 720 & 900 \\
\hline 5 & 48.7 & 41.7 & 28.2 & 27.8 & 17.5 & 16.6 & 5.7 & 3.9 & 3645 & 3.240 \\
\hline 1.25 & 24.3 & 25034 & 18775 & 17.4 & 11.09 & 5.184 & 1.8 & 1.2 & 972 & 0.972 \\
\hline 0.5 & 20.8 & 17.03 & 16.7 & 15.6 & 11.09 & 1.296 & 0.729 & 0.486 & 0.405 & 0.405 \\
\hline
\end{tabular}

\section{Effect of drying methods on the essential oil yield:}

The effect of drying methods on the essential oil yield of mint leaves is illustrated in table (2). The essential oil yield of mint leaves remarkably affected by using the different drying methods (microwave drying, oven drying and solar drying) at the three loading levels (5, 1.25 and 0.5 $\mathrm{kg} / \mathrm{m}^{2}$ ). Generally, drying the plant material before distillation might be resulted in increasing or reducing the essential oil yield depending on time of drying and temperature Hamrouni-Sellami et al. (2011).

The highest oil yield $(1.116 \mathrm{ml} / 100 \mathrm{~g}$. dry weight) was obtained from fresh sample plant. Drying the mint leaves by electric oven $\left(50^{\circ} \mathrm{C}\right.$ and $1.25 \mathrm{~kg} / \mathrm{m}^{2}$ loading level) reduced the yield to $0.68 \mathrm{ml} / 100 \mathrm{~g} \mathrm{~d}$. w., meanwhile increasing the drying temperature and loading to $70{ }^{\circ} \mathrm{C}$ and $5 \mathrm{~kg} / \mathrm{m}^{2}$ decreased the oil yield to $0.08 \mathrm{ml} / 100 \mathrm{~g} \mathrm{~d}$. w. With using direct solar drying, the highest yield was $0.60(\mathrm{ml} / 100 \mathrm{~g}$. d. m.)at 1.25 and 0.5 $\mathrm{kg} / \mathrm{m}^{2}$ loading. The essential oil content of mint leaves was completely lost when the leaves dried at various microwave powers (except leaves dried at $360 \mathrm{~W}$ and $1.25 \mathrm{~kg} / \mathrm{m} 2$ loading which contained only 0.04 $\mathrm{ml} / 100 \mathrm{~g}$ ). The samples dried in the oven at $40,50{ }^{\circ} \mathrm{C}$ and solar drying 
retained $0.62,0.68$ and $0.60 \mathrm{ml} / 100 \mathrm{~g}$ (.d. b.) of essential oil yields, respectively. No clear differences was observed among the obvious three treatments. On the other side, oven drying at 60 and $70{ }^{\circ} \mathrm{C}$ retained 0.20 and $0.14 \mathrm{ml} / 100 \mathrm{~g}$ (d.b.), respectively, At all loading levels, the highest essential oil yields were obtained through oven drying method at $50^{\circ} \mathrm{C}$.In microwave drying, the high temperature resulting from microwave energy which used in drying decreased the essential oil yield. This may be due to at high temperatures, the biological structure of the oil glands of medicinal and aromatic plants can be affected and the epithelial cells in the dried samples of some sensible plants can be observed to have been collapsed.

Table (2) Effect of drying methods on the essential oil yield $(\mathrm{ml} / 100 \mathrm{~g}$. dry matar)

\begin{tabular}{|c|c|c|c|c|c|c|c|c|c|c|c|}
\hline & & \multicolumn{4}{|c|}{ Hot air temperature ( C ) } & $\begin{array}{c}\text { Solar } \\
\text { drying }\end{array}$ & \multicolumn{5}{|c|}{ Microwave power (W) } \\
\hline & & 40 & 50 & 60 & 70 & & 180 & 360 & 540 & 720 & 900 \\
\hline $5 \mathrm{~kg} / \mathrm{m}^{2}$ & 1.116 & 0.44 & 0.48 & 0.12 & 0.08 & 0.4 & 0 & 0 & 0 & 0 & 0 \\
\hline $1.25 \mathrm{k} \mathrm{g} / \mathrm{m}^{2}$ & 1.116 & 0.62 & 0.68 & 0.2 & 0.14 & 0.6 & 0 & 0 & 0 & 0 & 0 \\
\hline $0.5 \mathrm{~kg} / \mathrm{m}^{2}$ & 1.116 & 0.6 & 0.66 & 0.2 & 0.15 & 0.6 & 0 & 0 & 0 & 0 & 0 \\
\hline
\end{tabular}

\section{Effect of drying methods on Total chlorophyll content:}

Table (3) shows The degree of color change as affected by drying methods and loading levels. High temperature could lead to the replacement of magnesium in the chlorophyll by hydrogen, thereby converting chlorophylls to pheophytins (Rudra et $a$ l. 2008).

The impact on color change of oven dried mint leaves was increased when temperature increased from $40-50{ }^{\circ} \mathrm{C}$ to $60-70{ }^{\circ} \mathrm{C}$.This result agreed with (Maharaj and Sankat, 1996) in which slower rate of chlorophyll degradation was found with shorter drying process. From table (3) the chlorophyll a, b of dried mint leaves by varies microwave power was higher than other drying methods in this study. This could be due to shorter drying time of the microwave drying. Insignificant impact of drying temperature in this range on the color of hot air dried products was observed in a previous study of drying dasheen leaves. 
Comparing to the microwave drying, the hot air drying yielded dried mint leaves being darker, less green and more yellow.

Table (3) Chlorophyll (a, b) content in mint leaves $\mathrm{mg} / \mathrm{L}$

\begin{tabular}{|c|c|c|c|c|c|c|c|c|c|c|c|c|}
\hline \multirow{3}{*}{ 范 } & \multirow{3}{*}{ 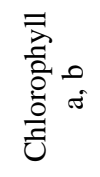 } & \multirow{3}{*}{ 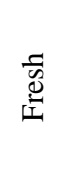 } & \multicolumn{10}{|c|}{ Drying methods } \\
\hline & & & \multicolumn{4}{|c|}{ Temperature } & \multirow{2}{*}{$\begin{array}{l}\frac{\hbar}{0} \\
\dot{0}\end{array}$} & \multicolumn{5}{|c|}{ Microwave drying (W) } \\
\hline & & & 40 & 50 & 60 & 70 & & 180 & 360 & 540 & 720 & 900 \\
\hline \multirow[b]{2}{*}{5} & Ch. a & 42 & 9 & 10 & 7 & 6 & 8 & 21 & 16 & 14 & 13 & 13 \\
\hline & Ch. b & 24.6 & 3 & 4 & 2 & 2 & 3 & 7.8 & 5 & 4 & 3 & 3 \\
\hline \multirow{2}{*}{1.25} & Ch. a & 42 & 14 & 15 & 11 & 10 & 11 & 26 & 27 & 24 & 22 & 21 \\
\hline & Ch. b & 24.6 & 4 & 5 & 3 & 2 & 5 & 12 & 11 & 10 & 8 & 8 \\
\hline \multirow[b]{2}{*}{0.5} & Ch. a & 42 & 13 & 14 & 10 & 9 & 12 & 25 & 26 & 23 & 20 & 20 \\
\hline & Ch. b & 24.6 & 4 & 5 & 3 & 3 & 5.6 & 11 & 10 & 10 & 7 & 7.5 \\
\hline
\end{tabular}

\section{Mathematical model of drying curves:}

Drying curves were simulated using empirical models of reduced moisture content. These empirical models coming from the fundamental diffusion models are generally suitable for fruits.

The drying data as the moisture ratio (MR) versus drying time were fitted to the eleven drying models. The predicted (MR) of the mint were obtained using the Data fit computer program. Tables (4), (5) and (6) show the drying model coefficients and the comparison criteria used to evaluate goodness of fit, namely the coefficient of determination $\left(\mathrm{R}^{2}\right)$, the reduced Chi-square $\left(\chi^{2}\right)$, and mean bias error (MBE) for oven drier, solar drier and microwave drier. The values of $\mathrm{R}^{2}, \chi^{2}$ and MBE for models range from 0.99782 to $0.9999964,2.97257 \mathrm{E}-9$ to $2.46666 \mathrm{E}-4$, and 5.08333E-5 to 0.18236036, respectively. For oven and solar drying According to table (4) the Midili-kucuk model showed good agreement with the experimental data and gave the best result for mint samples For solar and oven drying at $70{ }^{\circ} \mathrm{C}$ with $0.5 \mathrm{~kg} / \mathrm{m}^{2}$ of loading rate. The values of $\mathrm{R}^{2}, \chi^{2}$, and MBE for microwave drying was 0.992399 to 0.99992 , $3.964 \mathrm{E}-9$ to, 0.00673 and -0.003233 to 0.0117096 , respectively, According to table (6) the logarithmic model showed good agreement 
with the experimental data and gave the best result for mint samples at 900 of microwave power and $5 \mathrm{~kg} / \mathrm{m}^{2}$ loading.

Table (4) Modeling of moisture ratio according to drying time for mint by oven drier.

\begin{tabular}{|c|c|c|c|c|c|c|c|c|c|}
\hline \multirow{2}{*}{ Load } & \multirow{2}{*}{$\mathrm{T}$} & \multirow[t]{2}{*}{ model } & \multicolumn{4}{|c|}{ Model parameters ( Coefficients) } & \multirow{2}{*}{$\mathrm{R}^{2}$} & \multirow{2}{*}{$\chi^{2}$} & \multirow{2}{*}{ MBE } \\
\hline & & & A & b & $\mathrm{k}$ & $\mathrm{n}$ & & & \\
\hline \multirow{4}{*}{$5 \mathrm{~kg} / \mathrm{m}^{2}$} & 40 & Midili-kucuk & 0.989 & $-1.1 \mathrm{E}-03$ & 0.162 & 1.063 & 0.999 & $2.72 \mathrm{E}-7$ & $1.0233 \mathrm{E}-4$ \\
\hline & 50 & page & - & - & 0.293 & 1.058 & 0.998 & 2.97E-9 & $1.275 \mathrm{E}-5$ \\
\hline & 60 & Midili-kucuk & 1.002 & - 3.E-03 & 0.335 & 1.141 & 0.998 & $1.89 \mathrm{E}-8$ & $3.37 \mathrm{E}-5$ \\
\hline & 70 & Midili-kucuk & 0.997 & $-3.8 \mathrm{E}-03$ & 0.406 & 1.070 & 0.999 & $3.69 \mathrm{E}-7$ & 1. $51 \mathrm{E}-4$ \\
\hline \multirow{4}{*}{$1.25 \mathrm{~kg} / \mathrm{m}^{2}$} & 40 & Midili-kucuk & 0.996 & $-9.2 \mathrm{E}-04$ & 0.461 & 1.149 & 0.998 & $5.08 \mathrm{E}-6$ & 0.182360 \\
\hline & 50 & Midili-kucuk & 0.998 & $-2.8 \mathrm{E}-04$ & 0.752 & 1.179 & 0.998 & $7.84 \mathrm{E}-6$ & $6.701 \mathrm{E}-4$ \\
\hline & 60 & Midili-kucuk & 1.000 & 2.7E-04 & 1.439 & 1.120 & 0.999 & $2.46 \mathrm{E}-4$ & $-1.057 \mathrm{E}-4$ \\
\hline & 70 & Midili-kucuk & 1.000 & $2.5 \mathrm{E}-04$ & 1.432 & 1.734 & 0.999 & $3.02 \mathrm{E}-7$ & $-1.295 \mathrm{E}-4$ \\
\hline \multirow{4}{*}{$0.5 \mathrm{~kg} / \mathrm{m}^{2}$} & 40 & Midili-kucuk & 0.993 & $-6.9 \mathrm{E}-04$ & 0.368 & 1.196 & 0.997 & $4.96 \mathrm{E}-6$ & 5.3609E-4 \\
\hline & 50 & Midili-kucuk & 1.000 & 4.2E-04 & 0.919 & 2.290 & 0.999 & $3.31 \mathrm{E}-6$ & $-4.55 E-4$ \\
\hline & 60 & Midili-kucuk & 1.000 & $2.1 \mathrm{E}-04$ & 1.545 & 1.579 & 0.999 & $1.19 \mathrm{E}-6$ & $-2.708 \mathrm{E}-4$ \\
\hline & 70 & Midili-kucuk & 1.000 & $4.2 \mathrm{E}-05$ & 3.670 & 0.611 & 0.999 & $4.65 \mathrm{E}-8$ & $-5.083 \mathrm{E}-5$ \\
\hline
\end{tabular}

Table (5) Modeling of moisture ratio according to drying time for mint by solar drier.

\begin{tabular}{|c|c|c|c|c|c|c|c|c|c|}
\hline \multirow{2}{*}{ Load } & \multirow{2}{*}{ Model } & \multicolumn{5}{|c|}{ Model parameters (Coefficients) } & \multirow{2}{*}{$\mathrm{R}^{2}$} & \multirow{2}{*}{$\chi^{2}$} & \multirow{2}{*}{ MBE } \\
\cline { 3 - 10 } & & $\mathrm{a}$ & $\mathrm{B}$ & $\mathrm{C}$ & $\mathrm{k}$ & $\mathrm{N}$ & & \\
\hline $5 \mathrm{k} / \mathrm{gm}^{2}$ & $\begin{array}{c}\text { Two term } \\
\text { exponential }\end{array}$ & 1.64 & & & 0.4238 & & 0.998 & $1.9 \mathrm{e}-4$ & $3.39 \mathrm{e}-3$ \\
\hline $1.25 \mathrm{~kg} / \mathrm{m}^{2}$ & Midili-kucuk & 1.00 & $3.2 \mathrm{E}-3$ & & 0.6828 & 1.7956 & 0.998 & $5.429 \mathrm{e}-5$ & $-1.83 \mathrm{e}-3$ \\
\hline $0.5 \mathrm{~kg} / \mathrm{m}^{2}$ & Midili-kucuk & 1.00 & $3.2 \mathrm{E}-3$ & & 0.6963 & 2.1702 & 0.999 & $5.8 \mathrm{e}-5$ & $-1.9 \mathrm{e}-3$ \\
\hline
\end{tabular}


Table (6) Modeling of moisture ratio according to drying time for mint by Microwave drier.

\begin{tabular}{|c|c|c|c|c|c|c|c|c|c|c|}
\hline \multirow{2}{*}{ Load } & \multirow{2}{*}{$\begin{array}{c}\text { Power } \\
\text { (W) }\end{array}$} & \multirow{2}{*}{$\begin{array}{c}\text { mode } \\
1\end{array}$} & \multicolumn{5}{|c|}{ Model parameters ( Coefficients) } & \multirow{2}{*}{$\mathrm{R}^{2}$} & \multirow{2}{*}{$\chi^{2}$} & \multirow{2}{*}{ MBE } \\
\hline & & & A & b & $\mathrm{C}$ & $\mathrm{k}$ & $\mathrm{n}$ & & & \\
\hline \multirow{5}{*}{$5 \mathrm{~kg} / \mathrm{m}^{2}$} & 900 & $\mathrm{~L}$ & 3.791 & - & -2.8006 & 7.603 & - & 0.999 & $2.06 \mathrm{E}-6$ & -0.00369 \\
\hline & 540 & $\mathrm{~L}$ & 19.530 & - & -18.448 & 1.214 & - & 0.993 & $2.22 \mathrm{E}-8$ & $2.0612 \mathrm{E}-5$ \\
\hline & 720 & $\mathrm{P}$ & - & - & - & 1.261 & 2.091 & 0.992 & 0.00673 & 0.011709 \\
\hline & 360 & W & -1.019 & -6.397 & - & & - & 0.997 & $8020 \mathrm{E}-4$ & -0.003233 \\
\hline & 180 & W & -3.908 & -5.316 & - & & - & 0.999 & $3.10 \mathrm{E}-5$ & 3.8641E-4 \\
\hline \multirow{5}{*}{$\begin{array}{c}1.25 \mathrm{~kg} / \\
\mathrm{m}^{2}\end{array}$} & 900 & W & -0.106 & 1.646 & - & & - & 0.997 & $6.12 \mathrm{E}-5$ & -0.001996 \\
\hline & 720 & W & -0.109 & 1.885 & - & & - & 0.996 & $1.06 \mathrm{E}-4$ & -0.002629 \\
\hline & 540 & $\mathrm{~L}$ & 1.8153 & - & -0.783 & 5.673 & - & 0.995 & $2.06 \mathrm{E}-5$ & -0.003629 \\
\hline & 360 & $\mathrm{~L}$ & 11.262 & - & -10.219 & 4.471 & - & 0.996 & $1.68 \mathrm{E}-7$ & $1.7916 \mathrm{E}-5$ \\
\hline & 180 & $\mathrm{~L}$ & 20.166 & - & -19.13 & 8.710 & - & 0.995 & $1.65 \mathrm{E}-6$ & $1.5584 \mathrm{E}-4$ \\
\hline \multirow{5}{*}{$\begin{array}{c}0.5 \mathrm{~kg} / \\
\mathrm{m}^{2}\end{array}$} & 900 & M & 0.999 & -2.475 & - & 0.434 & 1.440 & 0.999 & $3.86 \mathrm{E}-8$ & 4.633E-5 \\
\hline & 720 & M & 0.999 & -3.285 & - & 0.425 & 1.384 & 0.999 & $2.31 \mathrm{E}-9$ & $1.133 \mathrm{E}-5$ \\
\hline & 540 & M & 0.995 & -2.169 & - & 0.366 & 1.576 & 0.997 & $4.86 \mathrm{E}-6$ & $5.457 \mathrm{E}-4$ \\
\hline & 180 & M & 1.008 & -1.320 & - & 0.128 & 0.918 & 0.998 & $3.96 \mathrm{E}-9$ & $-1.335 \mathrm{E}-5$ \\
\hline & 360 & $\mathrm{P}$ & - & - & - & 0.123 & 1.715 & 0.995 & 0.0008 & 0.0081513 \\
\hline
\end{tabular}

\section{CONCLUSION}

Microwave drying resulted in a high temperature so it is not advisable to use for drying of medicinal and aromatic plants in order to obtain aromatic oils, including due to the sensitivity of aromatic oils to heat whereat works to removed them entirely. Solar drying is more suitable 
PROCESS ENGINEERING

for drying medicinal plants because it maintains much of the oil, furthermore its low cost. Oven drying (at $50{ }^{\circ} \mathrm{C}$ and load level $1.25 \mathrm{~kg} / \mathrm{m}^{2}$ ) could be a potent drying method of mint leaves since it maintain much of it's essential oil.

\section{REFERENCES:}

Akgul A. (1993) Spice science and technology. Turkish Association of Food Technologists. Publ. no 15. Ankara Turkey.

Akpinar EK. ( 2010) Drying of mint leaves in a solar drier and under open sun: Modeling, performance analyses. Energy Conversion and Management 51 2407-2418

Board, N, (2003) The complete technology book of essential oils (aromatic chemicals). S. 1: asia pacific Business press inc.

Bondaruk, J., Markowski, M., Blaszczak, W., (2007).Effect of drying conditions on the

Doymaz I.( 2006) Thin-layer drying behavior of mint leaves. J Food Eng, $74: 370-5$.

Drouzas, A.E., Tsami, E., Saravacos, G.D., 1999. Microwave/vacuum drying of model fruit gels. Journal of Food Engineering 39, 117-122.

during thermal degradation of chlorophyll in mint and coriander puree. Journal of Food Engineering 86, 379-387.

Ekechukwu, O. V (1999) "Review of solar-energy drying systems I: an overview of drying principles and theory". Energy Convers Manage; 40:593-613.

El-Awady, M. N., Mohamed, S. A., El-Sayed, A. S. and Hassanain, A. A. (1993). Utilization of solar energy for drying processes of agricultural products. Misr, J. Ag. Eng., 10(4):794-804. 
Elminir, H. K., Ghitas, A. E., El-Hussainy, F., Hamid, R., Beheary, M. M. and Abdel-Moneim, K. M. (2006). Optimum solar flat-plate collector slope: Case study for Helwan, Egypt. Energy Conversion and Management, 47: 624-637

El-Yateem, S. M. E. (1995) "Studies on the drying of some vegetables and fruits". M.Sc Thesis, Food Technology, Dep., Faculty of Agriculture, El-Minufiya University.

Ertekin, C. and Yaldiz, O. (2004). Drying of eggplant and selection of a suitable hin layer-drying model. Journal of Food Engineering;(53): 349-359

Fathima A, Begum K, Rajalakshmi D. (2001) Microwave drying of selected greens and their sensory characteristics. Plant Foods Human Nutr;56:303-11.

Ghanem, T. H. (2003). Improving Thermal Efficiency of A Flat Plate Solar Collector Using Nontraditional Coating Under Quasisteady conditions. Misr J. Ag. Eng., 20 (2): 498-514.

Gunhan T, Demir V, Hancioglu E, Hepbasli A(2005).Mathematical modelling of drying of bay leaves. Energy Convers Manage;46(11-12):1667-79.

Hamrouni-Sellami, I., Wannes, W.A., Bettaieb, I., Berrima, S., Chahed, T., Marzouk, B., Limam, F., (2011). Qualitative and quantitative changes in the essential oil of Laurus nobilis L. leaves as affected by different drying methods. Food Chem. 126, 691769.

Idlimam, A.; Ethmane Kane, C. S. and Kouhila, M. (2007). Single layer drying behavior of grenade peel in a forced convective solar drier .Revue des Energies Renouvelables , 10 (2): 191 - 203.

Keshek, M. H. A. (2007).Drying Characteristics of Some Vegetables and Fruits by Different Solar Drying Systems .M .Sc Thesis, 
Department of Agricultural Engineering, Faculty of Agriculture, Minofiya University, Egypt.

Maharaj, V., Sankat, C.K., (1996). Quality changes in dehydrated dasheen leaves effect of blanching pre-treatments and drying conditions. Food Research International 29, 563-568. Engineering, 48, 177-182.

Maskan A, Kaya S, Maskan M. (2002) Hot air and sun drying of grape leather (pestil). J Food Eng;54:81-8.

Maskan, M. (2001). Drying, shrinkage and rehydration characteristics of kiwifruits during hot air and microwave drying. Journal of Food Engineering, 48, 177-182.

nutritional and sensory quality of leafy vegetables. Plant Foods for Human Nutrition 37, 291-298.

Omidbaigi R, Sefidkon F, Kazemi F (2004). Influence of drying methods on the essential oil content and composition of Roman chamomile. Flavour Fragr. J., 19: 196-198.

Onayemi, O., Okeibuno Badifu, G.I., (1987). Effect of blanching and drying methods on

Ozbek B, Dadali G. (2007). Thin-layer drying characteristics and modelling of mint leaves undergoing microwave treatment. J Food Eng;83(4):541-9.

quality of vacuum-microwave dried potato cubes. Journal of Food Engineering81, 164-175.

Radünz LL (2004). Dried rosemary pepper, and mint together on guaco different temperatures and its influence on the quantity and quality of active ingredients. $\mathrm{PhD}$ dissertation, University of Viçosa, Viçosa, Brazil. 
Rahimmalek, M., Goli, S.A.H., (2013). Evaluation of six drying treatments with respect to essential oil yield, composition and color characteristics of Thymus daenensis subsp. daenensis. Celak leaves. Ind Crops Prod. 42, 613-619.

Rudra, S.G., Singh, H., Basu, S., Shivhare, U.S., (2008). Enthalpy entropy compensation

Soysal, A., Oztekin, S., Eren, O., (2006). Microwave drying of parsley: modeling, kinetics, and energy aspects. Biosyst. Eng. 93 (4), 403- 413 .

Therdthai N, Zhou W. (2009) Characterization of microwave vacuum drying and hot air drying of mint leaves (Mentha cordifolia Opiz ex Fresen). J Food Eng;91:482-9.

Venskutonis PR (1997).Effect of drying on the volatile constituents of thyme (Thymus vulgaris L.) and sage (Salvia officinalis L.). Food Chem., 59: 219-227

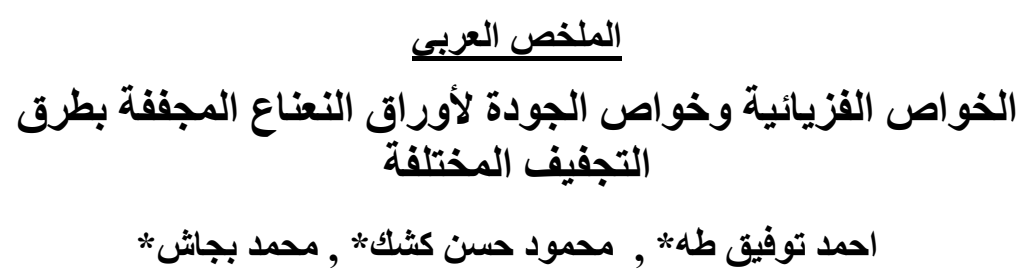

استخدمت ثلاث طرق لتجفيف اوراق النعناع وهي التجفيف بالفرن الكهربائى عند درجات

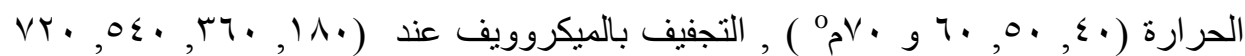

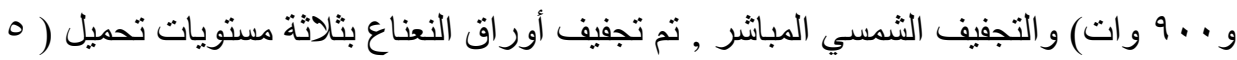

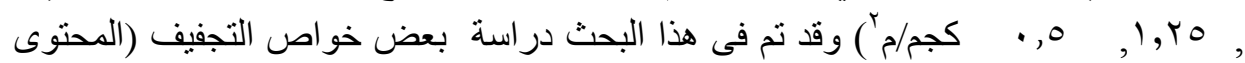

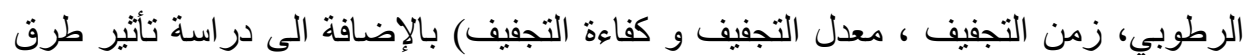

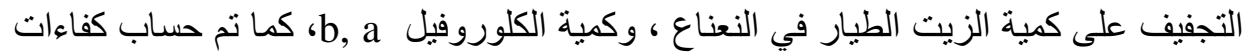

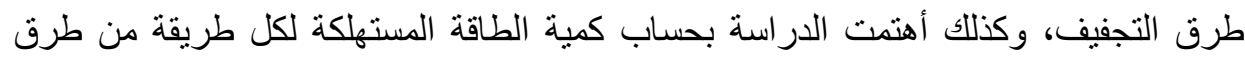
التجفيف المستخدمة في البحث وأيضا إستنتاج النماذج الرياضية المناسبة لوصف سلوك

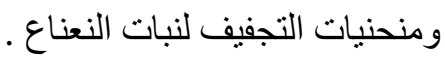

*قمم الهندسة الزراعية ـ كلية الزراعة ـ جامعة المنوفية 


\section{وكاتت اهم النتائج المتحصل عليها كما يلي:}

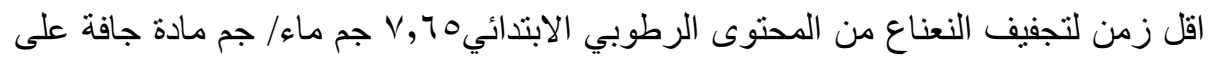

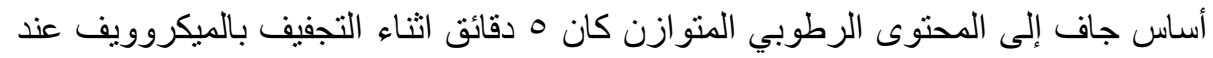

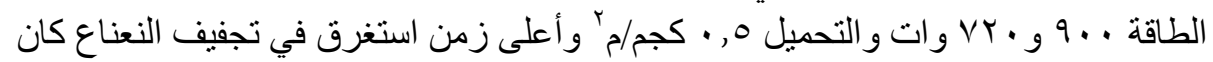

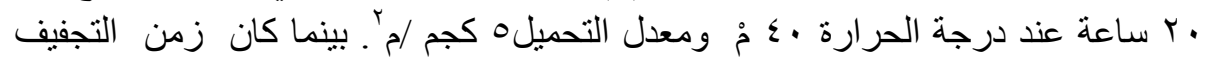

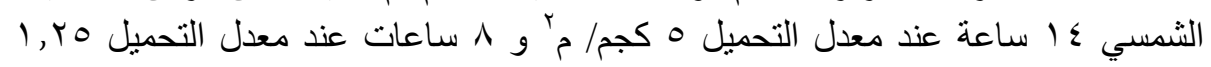

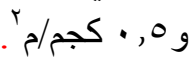

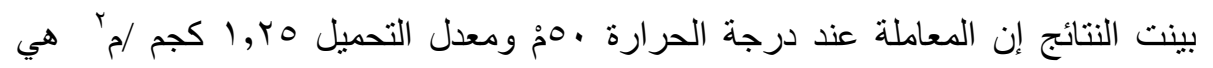
الأفضل في الحصول على اعلي كمية من الزيت مقارنة بدرجات الحرارة ومعدلات التحميل الأخرى.

هما بينت النتائج أن التجفيف بالميكروويف يعمل على تبخير الزيت العطري بالكامل الا انه

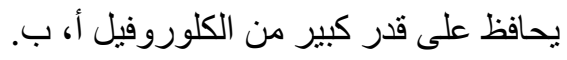

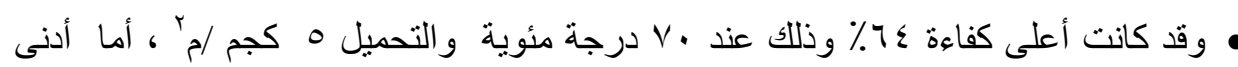

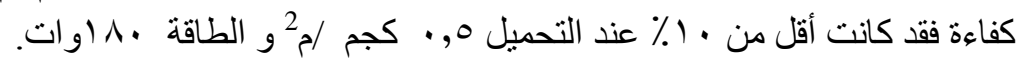

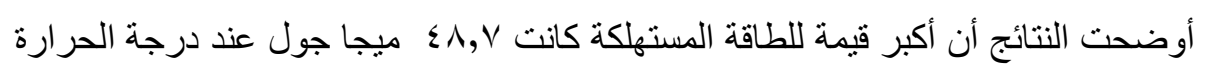

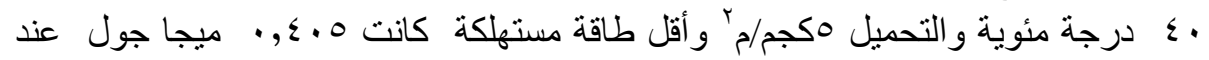

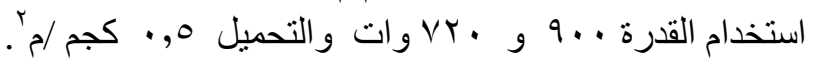

